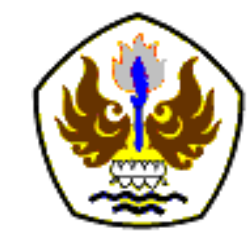

INFOMATEK

Volume 20 Nomor 2 Desember 2018

\title{
IMPLEMENTASI DATA MART PENJUALAN PADA PT. SINKHOKKI
}

\author{
Po. Abas Sunarya, Ignatius Joko Dewanto*), Samuel David Tiwa \\ Magister Teknik Informatika \\ Sekolah Tinggi Manajemen Informatika dan Komputer Raharja
}

\begin{abstract}
Abstrak: Permasalahan penjualan dengan sepenuhnya menggunakan IT adalah sulit sepenuhnya untuk menentukan perencanaan pasokan dan penjualan PT. Sinkhokki belum lagi yang menyangkut peraturan dan kendala yang menyangkut aspek UU ITE, tujuan penelitian ini adalah melakukan rekayasa IDM (Independent Data Mart) dengan sinkronisasi antara basis data departemen penjualan dan departemen gudang dari PT. Sinkhokki sehingga menjadi sebuah independent data mart. Sinkronisasi dilakukan melalui proses ETL (Extracts, Transformations dan Loading). Analisis data mart Kimball, pengembangan sistem Agile. Tools yang digunakan Xamp dengan peralatan Apache, PHP, dan MySql, serta pengembangan dashboard. Keluaran Independent Data Mart ini datanya dapat digunakan bagian gudang dan bagian penjualan yang datanya dapat digunakan dalam pengambilan keputusan strategis dan bisnis gudang dan penjualan. Tindak lanjut penelitian dapat memprediksi penjualan yang akan datang, sebagai dasar pengambilan keputusan manajemen PT. Sinkhokki.
\end{abstract}

Kata kunci: Agile, ETL, Independent Data Mart, Kinball , UU ITE

\section{PENDAHULUAN}

PT. SINKHOKKI merupakan perusahaan yang bergerak di bidang ritel bak cuci piring \& sanitary. Dalam kegiatan operasionalnya, perusahaan ini telah memiliki sistem informasi, akan tetapi sistem ini didukung oleh beberapa basis data yang belum terintegrasi sehingga penyajian informasi yang dibutuhkan untuk analisis dan pengambilan keputusan kurang efisien. Departemen Gudang dan Departemen Penjualan, merupakan dua departemen utama dalam proses bisnis di perusahaan ini.

*) jokodewanto@raharja.info

Pertama diterima : 27 April 2018

Direvisi : 22 Mei 2018

Disetujui untuk publikasi: 10 Juli 2018
Masing-masing departemen memiliki basis datanya sendiri-sendiri. Lokasi basis data operasional yang berbeda-beda ini mengakibatkan penarikan data untuk pelaporan menjadi tidak efisien karena kesulitan dalam melakukan integrasi data dari basis data yang satu dengan basis data yang lain.

Masalah yang tidak kalah pentingya UU Republik Indonesia Nomor 11 Tahun 2018 tentang Informasi dan Transaksi Elektronik (UU ITE, [1]), yaitu merupakan informasi yang valid serta tidak bertentangan dengan hukum yang berlaku atau Dashboard yang dapat mendukung pengambilan keputusan bagi 
manajemen mengenai jumlah transaksi pemasukan dan pengeluaran stock dan fluktuasi angka penjualan barang. Solusi terhadap permasalahan diatas adalah dengan melakukan sinkronisasi kedua basis data yang tidak terintegrasi menjadi sebuah Independent Data Mart yang dapat menyimpan data untuk proses pelaporan dan menyediakan informasi bagi analisis dan pengambilan keputusan bagi manajemen perusahaan PT. SINKHOKKI.

\section{METODOLOGI}

\subsection{Analisis Penelitian}

Analisis penelitian untuk jurnal ini menggunakan pendekatan metode dari ahli data mart Ralph Kimball, yang menjelaskan bahwa dalam melakukan analisis penelitian tersebut harus mencakup 10 langkah untuk menciptakan Sistem ETL (Extraction Transformation Loading), yaitu:

1. Draw the High-Level Plan

2. Choose an ETL Tool

3. Develop Default Strategies

4. Drip Down by Target Table

5. Populate Dimension Table with Historic Data

6. Perform the Fact Table Historic Load

7. Dimension Table Incremental Processing

8. Fact Table Incremental Processing

9. Aggregate Table and OLAP Loads

10. ETL System Operation and Automation

\subsection{Perencanaan Penelitian}

Melihat dari analisis penelitian yang sudah dibahas diatas, maka dapat dibuat alur perencanaan penelitian dengan mengacu pada pendekatan Kimball. Perencanaan penelitian tersebut dapat dialurkan seperti di bawah ini:

- Memilih proses bisnis

- Mendeklarasikan proses bisnis

- Memilih dimensi proses bisnis

- Mengidentifikasi fakta pada proses bisnis.

\subsection{Desain Penelitian}

Desain penelitian untuk jurnal ini adalah studi kasus, yang bertujuan untuk melakukan penelitian atau uji coba dimana hasil dari penelitian ini nantinya akan menyelesaikan masalah dengan cara mengambil keputusan berdasarkan dengan data yang dihasilkan.

Pada siklus hidup pengembangan sistem informasi, tahap implementasi dapat dijalankan dengan strategi pilot project yaitu mengimplementasikan sistem baru pada salah satu bagian dalam organisasi untuk dapat digeneralisasi.

Adapun desain pengembangan aplikasinya diterapkan agile system development di mana tidak ada satu konsep yang disepakati dalam pengembangannya. Namun demikian pada kenyatannya agile system telah mampu melahirkan banyak teknik-teknik praktis dalam pelaksanaanya baik itu temuan baru maupun hasil penelitian lanjutan atas konsep-konsep yang telah ada (Abrahamsson, [2]). 
Pembangunan data warehouse dan memanfaatkan OLAP dalam menganalisis data dengan pola penjualan marketing mix adalah alternatif solusi yang dapat dilakukan dalam penelitian ini untuk membantu organisasi khususnya dibagian pemasaran mencari dan memahami pola-pola tersembunyi (hidden pattern) dari data yang dimiliki perusahaan (Arifin, [3]). BI merupakan data mining untuk pengambilan keputusan (Vercellis, [4]).

Penerapan agile system memungkinkan pengembangan aplikasi dengan sejumlah kecil personil yang terlibat. Juga sangat fleksibel dalam hal pengembangan yang bersifat parsial dan insidental. Kaitannya dengan penelitian ini, pengembangan yang dilakukan menganut implementasi pilot project yang bersifat parsial, pelaksanaannya pun tidak menutup kemungkinan secara paralel, sehingga perbaikan di satu bagian akan segera diikuti pada bagian lainnya. Ini sangat sesuai dengan konsep agile system. Berikut adalah perbedaan fleksibilitas pengembangan sistem dengan waterfall dan agile, pada Gambar 1.

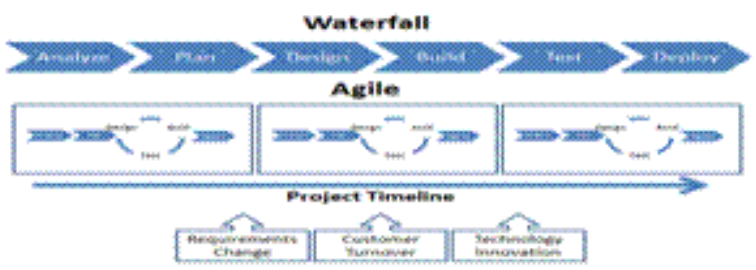

Gambar 1.

Waterfall vs Agile.
Metode yang digunakan pada penelitian ini adalah konsep Agile Software Development dicetuskan oleh Kent Beck dan 16 rekannya dengan menyatakan bahwa Agile Software Development adalah cara membangun software dengan melakukannya dan membantu orang lain membangunnya sekaligus.

Agile Method juga dapat diartikan sebagai metodologi pengembangan software yang didasarkan pada prinsip-prinsip yang sama atau pengembangan sistem jangka pendek yang memerlukan adaptasi cepat dari pengembangan terhadap perubahan dalam bentuk apapun.

$>$ Use Case Diagram

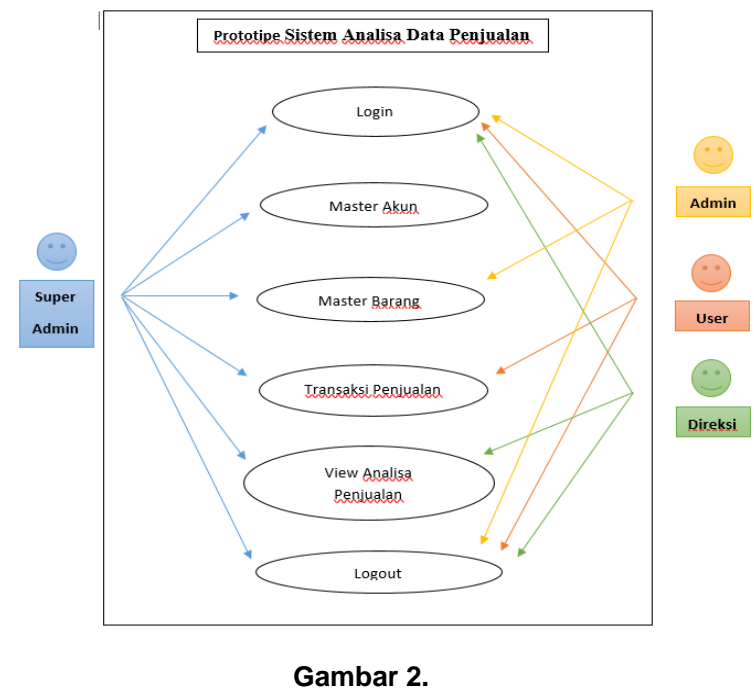

Use Case Diagram pada Aplikasi Penjualan 
Diagram use case diatas mengambarkan protipe Sistem Analisis Data Penjualan pada masing - masing akun didalam aplikasi penjualan, yang terdiri dari:

a. Akun Admin meliputi area akses, yaitu: Login, Master Barang, Logout.

b. Akun User meliput area akses, yaitu: Login, Transaksi Penjualan, Logout

c. Akun Direksi meliputi area akses, yaitu: Login, View Analisa Penjualan, Logout.

d. Akun Super Admin meliputi akses, yaitu: Login, Master Barang, Master Akun, Transaksi Penjualan, View Analisa Penjulaan, Logout.

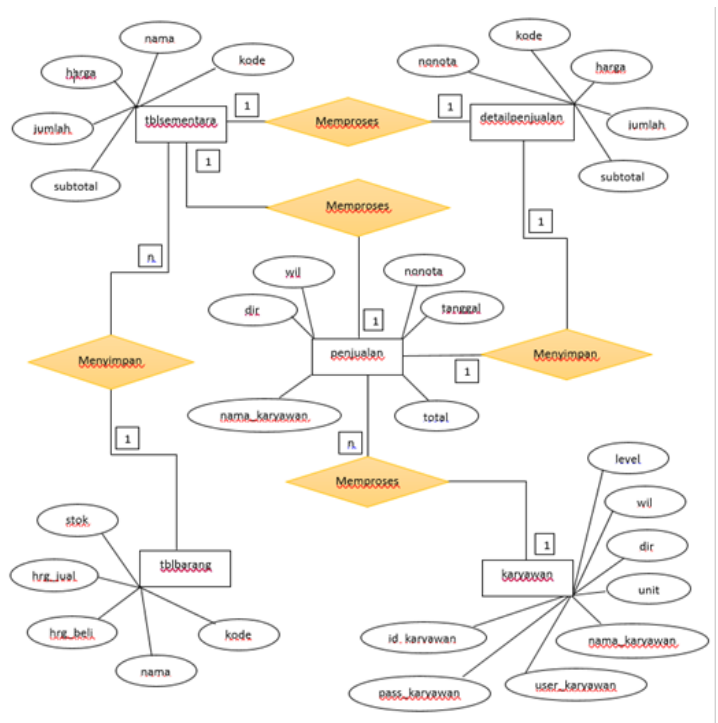

Gambar 3.

Class Diagram.

$>$ Activity Diagram

Berdasarkan gambar di atas dikondisikan bahwa masing-masing akun telah login dan masuk sesuai hak aksesnya, untuk selanjutnya dapat dijelaskan sebagai berikut:

1. Berawal dari pengumpulan data barang.

2. Data tersebut diterima oleh admin.

3. Akun Admin melakukan proses input, edit, delete, dan update data barang.

4. Akun User menerima data barang melalui sistem.

5. Akun User akan melakukan verifikasi barang, apakah sudah sesuai dengan data, jika ya lanjut ke proses selanjutnya, jika data akan kembali ke proses no.4.

6. Akun User melakukan proses transaksi penjualan ke dalam sistem.

7. Sistem menampilkan nota penjualan.

8. Sistem menampilkan data laporan analisis hasil penjualan ke dalam akun admin \& akun direksi

9. Akun Direksi (Top Management) menerima data laporan \& analisis hasil penjualan didalam sistem.

10. Akun Direksi (Top Management) menentukan perencanaan penjualan jangka pendek \& panjang.

11. Akun Direksi (Top Management) menyiapkan dan mengirimkan perencanaan jangka pendek \& jangka panjang kepada setiap unit / departemen. 


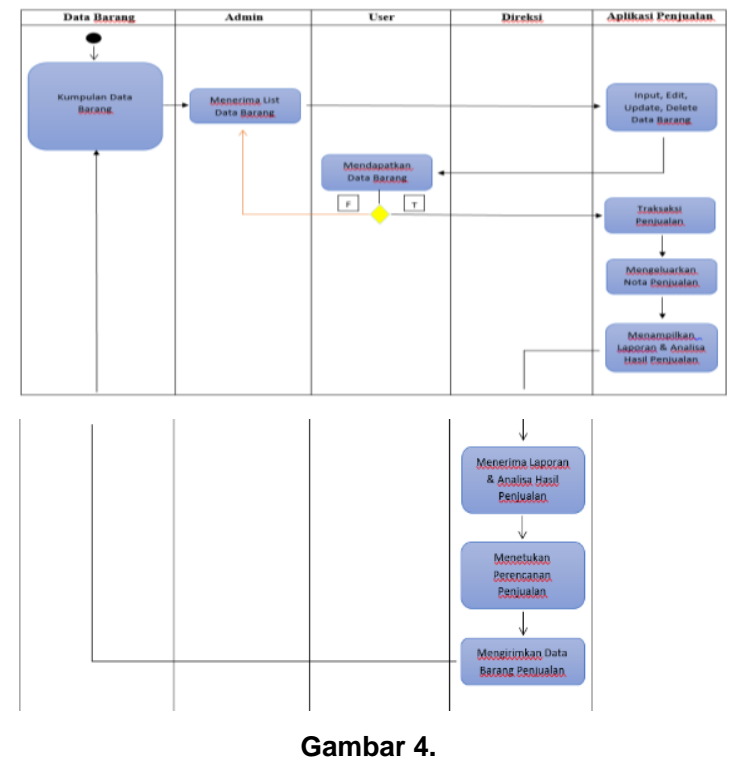

Activity Diagram pada Aplikasi Penjualan.

\section{$>$ Rich Picture}

Rich picture berikut menggambarkan sistem penjualan yang akan dibuat pada Aplikasi Penjualan.

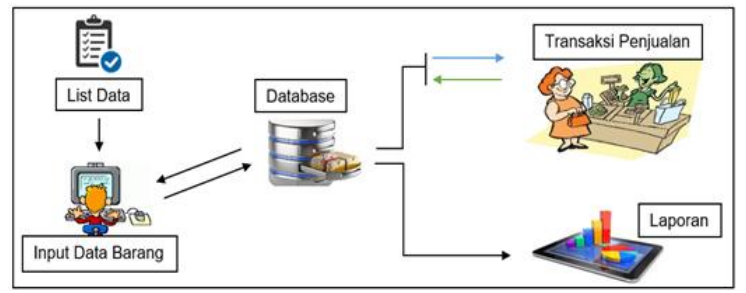

Gambar 5.

Rich Picture pada Aplikasi Penjualan

Proses analisis sistem ini diawali dengan list data barang yang dipersiapkan, yang kemudian dimasukkan ke dalam database melalui sistem, setelah data sudah ada di dalam database maka data tersebut akan digunakan bagian penjualan (user) untuk melakukan transaksi. Setelah itu data dari transaksi penjualan terkirim ke dalam database dari setiap proses transaksi yang ada, dan selanjutnya hasil dari inputan baik itu Input Barang \& Input Transaksi akan diolah sistem hingga membentuk laporan secara live dan tepat yang dapat diolah manajemen atas untuk mengambil keputusan strategi penjualan selanjutnya.

\section{> Analisis Database}

Berdasarkan analisis kebutuhan atas sistem aplikasi penjualan, maka didapatkan data-data yang berhubungan di dalam database aplikasi penjualan

Berikut ini list tabel yang dimana terdapat 5 tabel yang saling berelasi:

1. Tabel detailpenjualan merupakan tabel yang berisikan detail hasil transaksi penjualan : Nonota (no nota) (PK), kode (kode barang), Harga (harga barang), jumlah (jumlah barang, subtotal

2. Tabel karyawan berisi data karyawan sebagai user di dalam aplikasi penjualan: Id_karyawan (PK), Pass_karyawan, User_karyawan, Nama_karyawan, Unit, Dir (Direktorat), Wil (Wilayah), Level

3. Tabel penjualan adalah berisikan tentang proses transaksi penjualan : Nonota (PK), Tanggal (tanggal penjualan barang), Total Pendapatan (total pendapatan per transaksi), Nama_karyawan, Dir (Direktorat), Wil (wilayah) 
4. Tabel tblbarang adalah tabel yang berisikan detail data barang penjualan : Kode Barang(PK), Nama (nama barang0, Hrg_beli, Hrg_jual, Stok Barang

5. Tabel tblsementara adalah tabel yang berisikan tentang proses suatu transaksi, dimana data tersebut sebelum eksekusi data penjualan maka data barang akan dimasukkan ke dalam data tblsementara untuk menentukan data barang mana yang akan dieksekusi di setiap 1 transaksi penjualan : Kode (Null), Nama, Harga (harga barang), Jumlah, subtotal.

\section{ANALISIS DAN PEMBAHASAN}

Hasil dari penelitian ini akan disajikan dengan print screen tahapan tabulasi yaitu proses data yang diolah untuk menganalisa output data yang ditampilkan beserta penjelasannya.

\subsection{Analisis Kebutuhan Aplikasi Penjualan}

Data dan informasi yang dibutuhkan oleh pihak top management dalam menganalisis dan pengambilan keputusan berkaitan dengan penentuan strategi penjualan adalah sebagai berikut:

1. Laporan mengenai fluktuasi naik turunnya penjualan suatu barang tertentu yang dapat digambarkan dengan perolehan omset penjualan dalam tiap periode waktu.

2. Laporan mengenai sisa stok penjualan, total pendapatan, dan pendapatan bersih penjualan yang dirangkum pada Laporan Keuangan

3. Laporan mengenai transaksi penjualan dan barang terbanyak terjual yang dirangkum pada Laporan Detail Penjualan.

4. Laporan mengenai user transaksi, user terbanyak proses pendapatan transaksi yang dirangkum pada Laporan User Transaksi.

\subsection{Analisis Perancangan Data Mart}

Analisis perancangan data mart penjualan pada PT. Sinkhokki menggunakan pendekatan Kimball. Adapun 10 langkah Ralph Kimbal untuk menciptakan Sistem ETL.

\section{Draw the High-Level Plan}

Draw the High-Level Plan adalah Mendesain skema yang sangat sederhana setiap bagian bagian kecil dari perencanaan, sumber dan target.

Melihat dari langkah no.1, sesuai dengan kebutuhan perusahaan maka dapat dibuat skema tabel database penjualan.

Tabel 2 adalah tampilan dari database pada aplikasi penjualan. 
Tabel 2.

Struktur Database Penjualan

\begin{tabular}{|c|c|c|}
\hline Nama Tabel & Field & Type (Values) \\
\hline \multirow{8}{*}{ karyawan } & id_karyawan & int (10) \\
\hline & pass_karyawan & varchar (50) \\
\hline & user_karyawan & varchar (50) \\
\hline & nama_karyawan & varchar (50) \\
\hline & Unit & varchar (20) \\
\hline & Dir & varchar (30) \\
\hline & Wil & varchar (100) \\
\hline & Level & int (5) \\
\hline \multirow{5}{*}{ tblbarang } & Kode & varchar (10) \\
\hline & Nama & varchar (100) \\
\hline & hrg_beli & int (5) \\
\hline & hrg jual & int (5) \\
\hline & Stok & int (5) \\
\hline \multirow{5}{*}{ tblsementara } & Kode & varchar (10) \\
\hline & Nama & varchar (100) \\
\hline & Harga & int (8) \\
\hline & Jumlah & int (8) \\
\hline & Subtotal & int (8) \\
\hline \multirow{6}{*}{ Penjualan } & Nonota & varchar (8) \\
\hline & Tanggal & Date \\
\hline & Total & int (8) \\
\hline & nama_karyawan & Varchar (100) \\
\hline & Dir & Varchar (100) \\
\hline & Wil & Varchar (100) \\
\hline \multirow{5}{*}{ Detailpenjualan } & Nonota & varchar (10) \\
\hline & Kode & varchar (8) \\
\hline & Harga & int (8) \\
\hline & Jumlah & int (8) \\
\hline & Subtotal & int (8) \\
\hline
\end{tabular}

\section{Choose an ETL Tool}

Choose an ETL Tool adalah Memilih perangkat ETL yang baik bagi standar operasional industri. Melihat dari langkah no.2, sesuai dengan kebutuhan perusahaan maka dapat dipilih ETL Tool: perangkat open source yaitu XAMPP (Phpmyadmin).

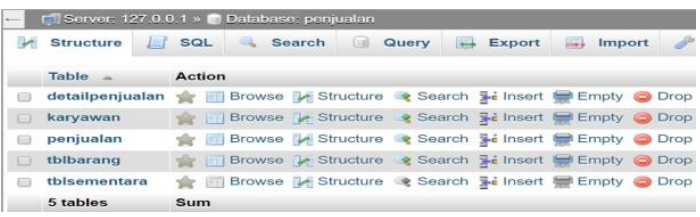

Gambar 6.

Database Penjualan (Phpmyadmin)

\section{Develop Default Strategies}

Develop Default Strategies adalah Mengembangkan suatu standar strategi untuk aktivitas atau alur di dalam Sistem ETL.

Melihat dari langkah no.3, sesuai dengan kebutuhan perusahaan maka dapat dibuat skema snowflake database sebagai berikut:

\section{Drop Down by Target Table}

Drop Down by Target Table adalah Proses kelanjutan dari pengembangan standar strategi, yaitu kita harus mendalami transformasi secara terinci yang diperlukan untuk mengisi setiap tabel di dalam data warehouse. Seperti penyempurnaan sumber data menjadi target pemetaan, dan juga mengidentifikasi data lain untuk benar-benar memahami transformasi data yang diperlukan untuk setiap tabel dan kolom. Melihat dari langkah no.4, sesuai dengan kebutuhan perusahaan maka dapat dibuat 2 kategori, yaitu:

- Transaction Entities: Entitas Tblbarang, entitas Tblsementara, entitas Penjualan, dan entitas Detailpenjualan.

- Component Entities: Entitas Tblbarang, entitas Penjualan dan entitas Karyawan.

\section{Populate Dimension Table with Historic Data}

Populate Dimension Table with Historic Data adalah Proses memulai membangun sistem 
ETL dengan tabel dimensi yang paling sederhana.

\section{Perform the Fact Table Historic Load}

Perform the Fact Table Historic Load adalah Proses mengidentifikasi catatan yang termaksud dalam parameter dasar ekstrak, dimana ini berguna untuk data warehouse.

Melihat dari langkah no.5 \& no.6, sesuai dengan kebutuhan perusahaan maka dapat dibuat Collapse Hierarchy yaitu: peleburan entitas level tertinggi ke entitas dengan level yang lebih rendah dalam hierarki.

\section{Dimension Table Incremental Processing}

Dimension Table Incremental Processing adalah Proses pengembangan sistem ETL Inkremental dimulai dengan tabel dimensi. Dimensi proses inkremental sangat mirip dengan proses historis diatas.

\section{Fact Table Incremental Processing}

Fact Table Incremental Processing adalah Proses pengolahan tabel fakta pada sistem ETL.

\section{Aggregate Table and OLAP Loads}

Aggregate Table and OLAP Loads adalah Proses pengolahan tabel yang menampilkan hasil kueri, dimana sistem ETL akan memperbaharui hasil tingkat agregat data yang lama menjadi hasil tingkat agregat data yang baru.

Melihat dari langkah no.7 sampai no.9, sesuai dengan kebutuhan perusahaan maka dapat dibuat skema snowflake sebagai skema perancangan model data dimension, dimana menentukan Tabel fakta dari pengolahan tabel dimensi yang ada pada sistem ETL dan dapat melakukan aggregation sebuah subset dari atribut yang terpilih dari sumber entitas yang ada untuk menciptakan entitas yang baru.

\section{ETL System Operation and Automation}

ETL System Operation and Automation adalah Proses sistem ETL yang berjalan sesuai dengan prosedur, dan tanpa intervensi user.

Melihat dari langkah no.10 maka dapat dianalisa bahwa setiap proses di dalam sistem ETL Data Mart Penjualan pada PT.VWX, merupakan hasil pengolahan sistem yang dimana proses tersebut benar-benar dilakukan oleh sistem ETL tanpa ada campur tangan atau intervensi user, sehingga laporan yang ditampilkan adalah real.

\subsection{Perancangan Data Mart}

Terkait informasi yang dibutuhkan oleh Top Management mengenai data yang ada di dalam database, maka data tersebut akan diolah oleh data mart menjadi 3 bagian, yaitu: Classify Entities, Identify Hierarchy, Dimensional Model. 


\subsection{Classify Entities}

Mengelompokan entitas ke dalam 2 kategori, yaitu sebagai berikut:

- Transaction Entities: Entitas Tblbarang, entitas Tblsementara, entitas Penjualan, dan entitas Detailpenjualan.

- Component Entities: Entitas Tblbarang, entitas Penjualan dan entitas Karyawan

\subsection{Identify Hierarchy}

Berdasarkan model entity relationship diagram (Gambar 7) aplikasi penjualan maka dapat dibuat beberapa hirarki antara lain :

- Hirarki pada kategori Transaction Entities
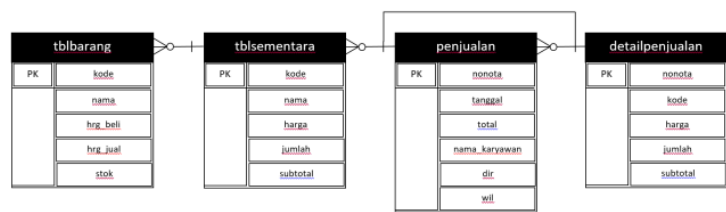

Gambar 7.

Hirarki Kategori Transaksi

- Hirarki pada kategori Component Entities
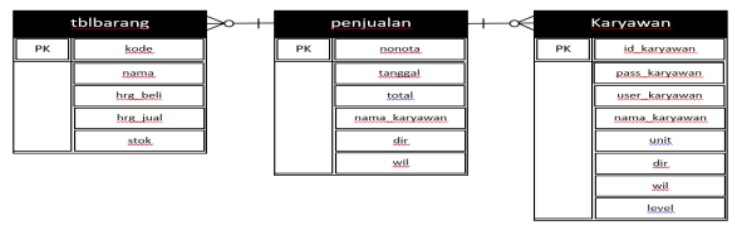

Gambar 8.

Hirarki Kategori Komponen

\subsection{Dimensional Model}

\section{- Collapse Hierarchy}

Collapse hierarchy yaitu peleburan entitas level tertinggi ke entitas dengan level yang lebih rendah dalam hierarki. Sebagai contoh entitas Penjualan dan entitas Tblsementara dilebur atau digabungkan ke dalam entitas Detail penjualan maka Entitas Detail penjualan akan berisi atribut asli ditambah dengan atribut yang berasal dari tabel yang digabung. Peleburan ini berlangsung hingga kategori Transaction Entities menjadi suatu hierarki, dan menyisakan satu entitas yang kemudian akan menjadi tabel dimensi.

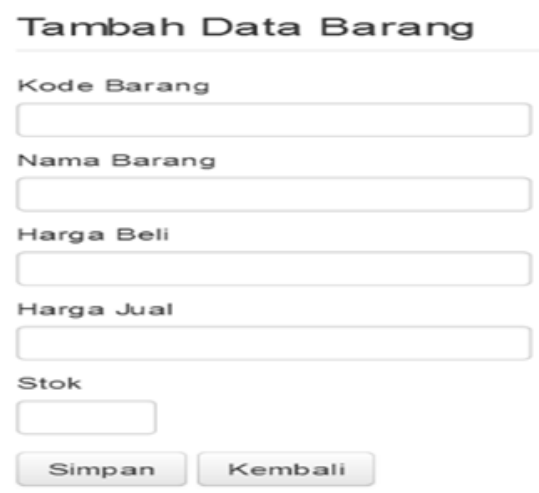

\section{Aplikasi Penjualan}

Aplik

Data Barang

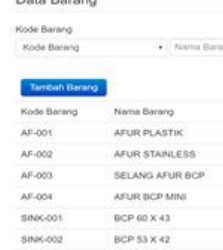

Aplikasi Penjualan

Aprikasi Penjualan

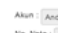

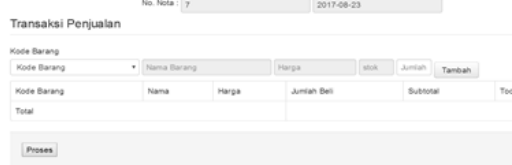




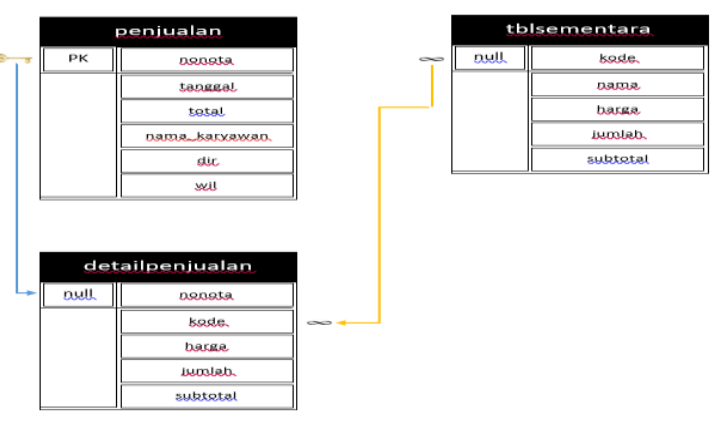

Gambar 9.

Collapse hierarchy tabel detail penjualan

\section{- Agregation}

Dapat diterapkan pada sebuah transaction entity untuk menciptakan sebuah entitas yang baru yang berisi data yang diringkas. Sebuah subset dari atribut dipilih dari entitas sumber untuk agregat (the aggregation attributes) dan harus berupa angka atau numerik. Skema snowflake sebagai skema perancangan model data dimensional pada perancangan data mart penjualan PT. SINKHOKKI. Seperti yang ditunjukkan pada Gambar 10.

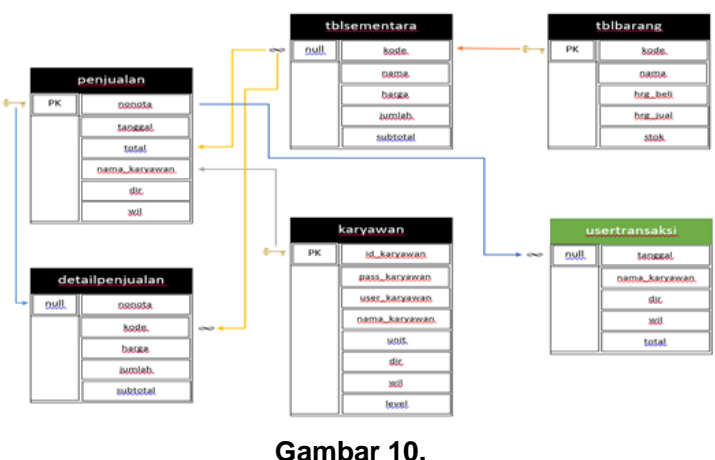

Skema snowflake entitas usertransaksi

\subsection{Analisis Hasil Perancangan Aplikasi Penjualan}

Berikut ini merupakan proses alur data yang menyajikan informasi yang efektif dan relevan pada Aplikasi Penjualan. Dimana semua proses pada aplikasi penjualan akan ditampilkan pada setiap akun di setiap hak aksesnya.

\section{Akun Admin}

Dimulai dari alur proses upload data barang ke dalam aplikasi penjualan (Gambar 11 \& Gambar 12) pada halaman home.php dan proses.php, dimana hasil dari halaman ini masuk ke dalam database list barang yang dibutuhkan untuk menjadi data penunjang dalam proses transaksi.

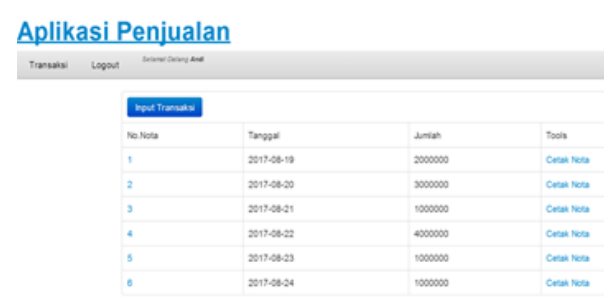

Gambar 11.

Master Barang

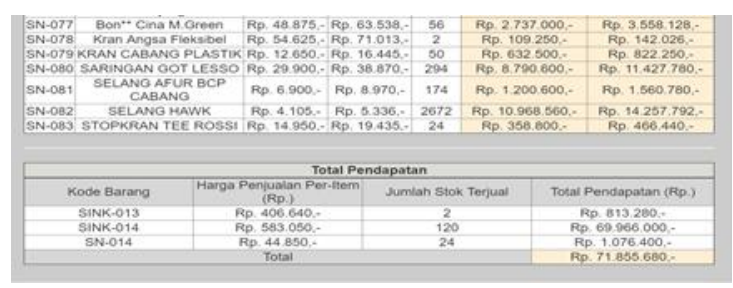

Gambar 12.

Tambah Data Barang

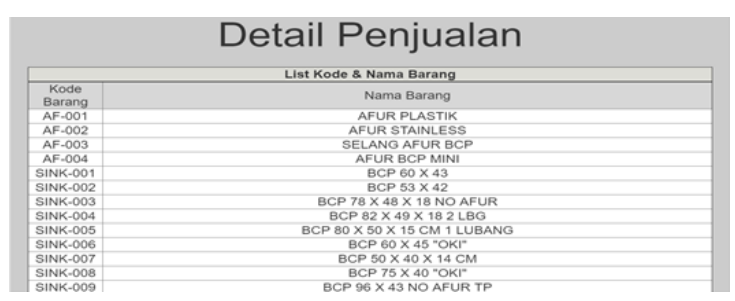

Gambar 13.

List Proses Transaksi 


\section{Akun User}

Dimulai dari halaman transaksi yang dilakukan pada akun user, dimana pertama ditampilkan adalah list transaksi yang sudah ada (Nota Penjualan), kemudian menekan tombol Input Transaksi untuk memulai proses transaksi yang ditampilkan pada Gambar 14 dan Gambar 15.

Gambar 15 adalah sebuah proses penelitian tahap akhir dari Dashboard dan Data Mart untuk menguji efektivitas proses pengolahan data menggunakan sistem Aplikasi Penjualan. Pada Grafik penjualan ini dapat dilihat bahwa manajemen atas (direksi) dapat mencari data transaksi melalui tanggal, nota transaksi, nama karyawan (kasir), wilayah, dan menampilkan data Total Pendapatan Terakhir \& Tanggal Terakhir Transaksi, serta List Keterangan berupa: Nama Karyawan, Tanggal Transaksi, Direktorat, Wilayah, dan Jumlah Transaksi. Sesuai dengan keyword.

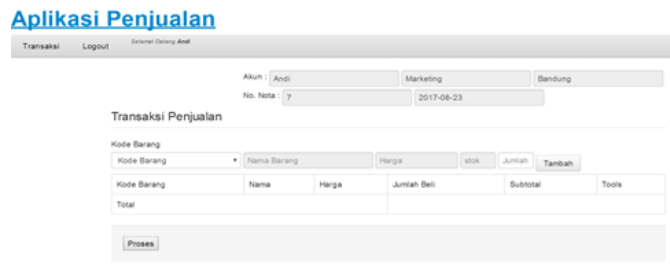

Gambar 14. Aplikasi Penjualan

\section{Akun Direksi (Top Management)}

Dimulai dari alur proses upload data barang ke dalam sistem aplikasi (Gambar 14 \& Gambar 15), dan kemudian dilanjutkan transaksi penjualan (Gambar 16 \& Gambar 17). Saat transaksi sudah selesai, maka direksi langsung mendapatkan laporan (Live Report) data penjualan pada halaman analisa, dan ditindaklanjuti untuk dijadikan data pengambil keputusan (Gambar 16, Gambar 17, Gambar 18, Gambar 19).

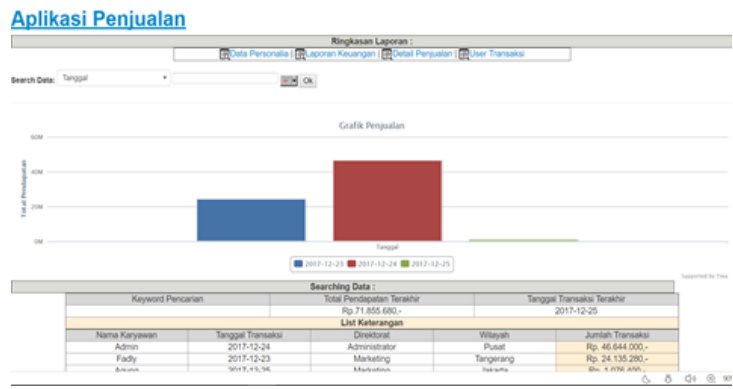

Gambar 15.

Grafik Penjualan

- Laporan Keuangan

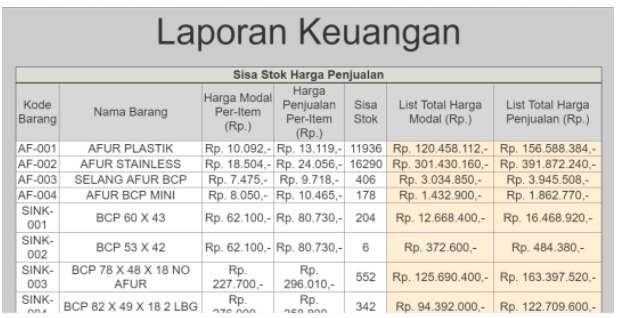

Gambar 16.

Laporan Keuangan 
Pada Laporan Keuangan ini dapat dilihat bahwa manajemen atas (direksi) dapat melihat beberapa laporan, sebagai berikut:

- Sisa Stok Harga Penjualan

$$
\begin{array}{ll}
\checkmark & \text { Kode Barang } \\
\checkmark & \text { Nama Barang } \\
\checkmark & \text { Harga Modal Per-Item } \\
\checkmark & \text { Harga Penjualan Per-Item } \\
\checkmark & \text { Sisa Stock } \\
\checkmark & \text { List Total Harga Modal } \\
\checkmark & \text { List Total Harga Penjualan } \\
\checkmark & \text { Total Pendapatan } \\
\checkmark & \text { Kode Barang } \\
\checkmark & \text { Harga Penjualan Per-Item } \\
\checkmark & \text { Jumlah Stock Terjual } \\
\checkmark & \text { Total Pendapatan (Rp.) }
\end{array}
$$

- Detail Penjualan

Aplikasi Penjualan

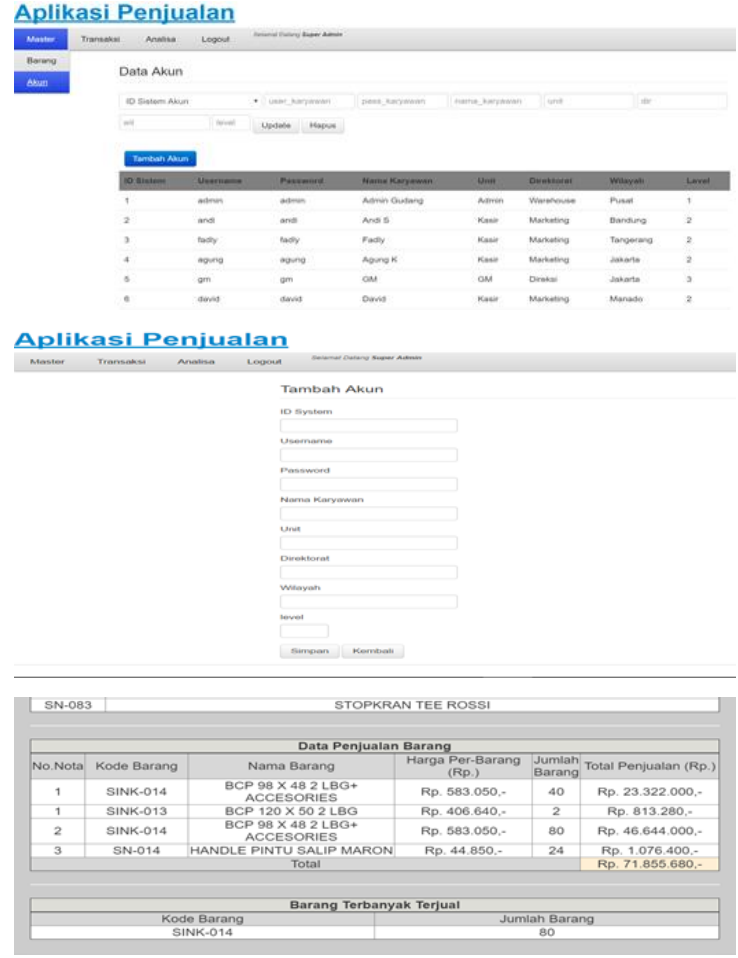

Gambar 17.

Detail Penjualan
Pada Laporan Detail Penjualan ini dapat dilihat bahwa manajemen atas (gm) dapat melihat beberapa laporan, sebagai berikut:

- $\quad$ List Kode \& Nama Barang

$$
\checkmark \text { Kode Barang }
$$

- Data Penjualan Barang

$\checkmark$ No.Nota

$\checkmark$ Kode Barang

$\checkmark$ Nama Barang

$\checkmark$ Harga Per-Barang

$\checkmark$ Jumlah Barang

$\checkmark$ Total Penjualan (Rp.)

- Barang Terbanyak Terjual

$\checkmark$ Kode Barang

$\checkmark$ Jumlah Barang

- User Transaksi

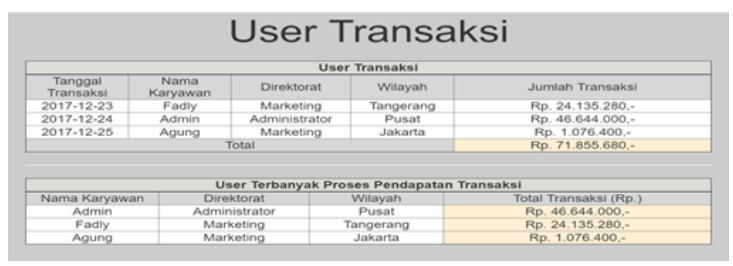

Gambar 18.

User Transaksi

Pada Laporan User Transaksi ini dapat dilihat bahwa manajemen atas (direksi) dapat melihat beberapa laporan, sebagai berikut:

- User Transaksi

$\checkmark$ Tanggal Transaksi

$\checkmark$ Nama Karyawan

$\checkmark$ Direktorat

$\checkmark$ Wilayah

$\checkmark$ Jumlah Transaksi

- User Terbanyak Proses

Pendapatan Transaksi

$\checkmark$ Nama Karyawan

$\checkmark$ Direktorat

$\checkmark$ Wilayah

$\checkmark$ Total Transaksi (Rp.) 


\section{Akun Super Admin}

Akun Super Admin memiliki seluruh hak akses yang dimiliki oleh akun admin, user, dan direksi (top management), dengan maksud agar dapat melakukan maintenance \& memonitor pergerakan sistem aplikasi agar tetap berjalan dengan baik.

Akun Super Admin memiliki hak akses yang tidak dimiliki oleh setiap user, yaitu: tambah, hapus, edit setiap akun yang ingin berinteraksi dengan sistem aplikasi penjualan. Pada Master Akun ini dapat dilihat bahwa Superadmin dapat memonitor akun aplikasi penjualan, dengan akses sebagai berikut:

- Master Akun
$\checkmark$ View
$\checkmark$ Update / Edit
$\checkmark$ Delete
$\checkmark$ Add / tambah

Pada Tambah Akun ini dapat dilihat bahwa Superadmin dapat menambah akun pada sistem, sebagai berikut:

- Tambah Akun
$\checkmark$ ID System
$\checkmark$ Username
$\checkmark$ Password
$\checkmark$ Nama Karyawan
$\checkmark$ Unit
$\checkmark$ Direktorat
$\checkmark$ Wilayah
$\checkmark$ Level

\section{Pengujian Sistem}

Teknik pengujian sistem yang dilakukan dalam penelitian ini menggunakan pendekatan standarisasi black box testing dengan menggunakan metode FGD (Forum Group Discussion). Peserta FGD merupakan pengguna yang terbatas dan dipilih oleh penulis untuk menjalankan dan memelihara prototipe aplikasi penjualan. Dan pengujian performa aplikasi dengan menggunakan command prompt (CMD)

- Pengujian Black Box

Pengujian black box adalah metode pengujian yang dilakukan dengan cara mengamati hasil eksekusi melalui data uji dan memeriksa fungsional sistem. Pengujian black box dapat dianalogikan seperti kita melihat suatu kotak hitam, kita hanya melihat penampilan luarnya saja, tanpa melihat detail proses dibalik hitam. Apabila dari input yang dilakukan, proses dalam sistem dapat menghasilkan output sesuai dengan kebutuhan fungsionalnya, maka program yang dibuat dinilai sudah berjalan dengan baik.

Untuk menilai kualitas sistem berdasarkan pengujian black box, peneliti membuat membuat 16 kasus pengujian di bawah ini: 1. Sistem menolak proses login, 2. Hanya menu master data tampil, 3. Hanya menu transaksi penjualan tampil, 4. Hanya menu analisis tampil, 5. Semu menu pada sistem tampil, 6. Dapat melakukan entry/edit/delete data, 7. Dapat melakukan hasil analisis data, 8. Dapat menampilkan tabel sis stok harga penjualan dan total pendapatan, 9. Dapat menampilkan tabel list kode \& nama barang, data penjualan barang, barang banyak terjual, 10 . Dapat 
menampilkan tabel user transaksi, dan user terbanyak proses pendapatan transaksi, 11. Dapat melakukan entry/ edit/ delete data master barang, 12. Mengisi username, password dengan lengkap dan benar lalu klik login, 13. Mengisi username, password Super Admin sistem dengan lengkap dan benar lalu klik login, 14. Mengisi username, password User sistem dengan lengkap dan benar lalu klik login, 15. Mengisi username, password Direksi sistem dengan lengkap dan benar lalu klik login, 16. Mengisi username, password Admin sistem dengan lengkap dan benar lalu klik login

- Pengujian Performa Aplikasi

Pada tahap ini merupakan analisa performa aplikasi dimana berfungsi untuk mengetahui performa aplikasi penjualan sebelum diakses oleh seluruh akun di dalam sistem. Hal ini dilakukan untuk mencegah failed access yang diakibatkan karena ada kerusakan pada sistem, dan pengujian ini menggunakan beberapa perangkat keras, perangkat lunak, editor program dengan detail seperti pada Tabel 3.

Pengujian pada tahap ini akan melalui command prompt (CMD) dimana kita akan menguji menggunakan perintah systeminfo, ping \& tracert di dalam command prompt pada Lenovo Yoga 500 dan Server Xampp dengan ip default
127.0.0.1, berikut adalah hasil tampilan pengujian (Gambar 19 dan Gambar 20).

Tabel 3.

Review Perangkat

\begin{tabular}{|l|l|}
\hline Nama & \multicolumn{1}{l|}{ Versi } \\
\hline Editor Program \& Perangkat Lunak : \\
\hline HTML & v5.0 \\
\hline PHP & - \\
\hline JavaScript & - \\
\hline JQuery & - \\
\hline CSS & - \\
\hline Xampp & v3.2.1 \\
\hline Notepad++ Home & v6.7.7 \\
\hline $\begin{array}{l}\text { Ms. Win 10 Hingle Language } \\
\text { Sing }\end{array}$ & $10.10586 /$ x64 \\
\hline Perangkat Keras : & Intel Core i5 5200U \\
\hline Processor & DDR3 4GB \\
\hline Memori & NVIDIA GeForce 940M \\
\hline Graphics
\end{tabular}

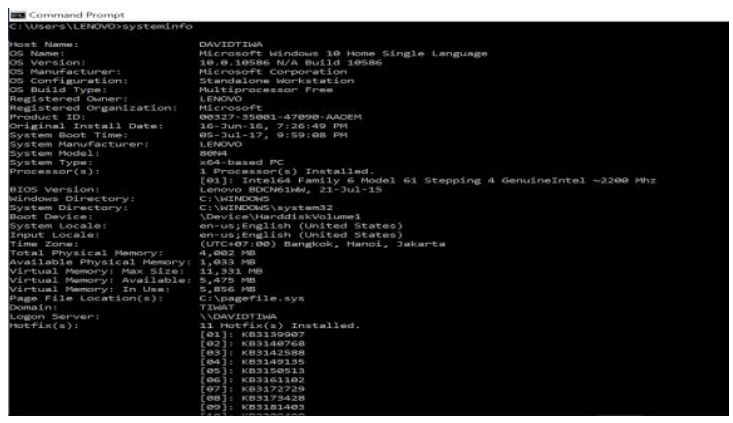

Gambar 19.

Syseminfo

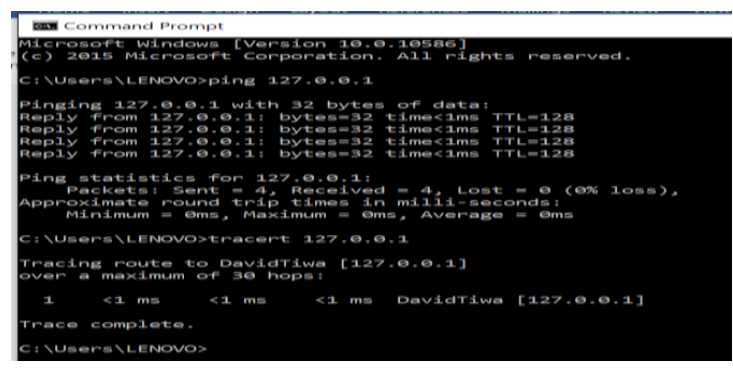

Gambar 20

Ping \& Tacert 
Pada hasil pengujian, respons yang didapatkan adalah:

$\checkmark$ Reply from 127.0.0.1: bytes $=32$ time $<1 \mathrm{~ms} T \mathrm{TT}=128$

$\checkmark$ Packets: Sent $=4$, Received $=4$, Lost $=$ 0 (0\% loss)

$\checkmark 1<1 \mathrm{~ms}<1 \mathrm{~ms}<1 \mathrm{~ms}$ DavidTiwa [127.0.0.1]

Paket data yang dikirimkan dan direspon oleh server tidak ada yang hilang [dikirim 4 dan diterima 4] , serta telah dilakukan tracert dengan waktu <1 ms. Berdasarkan hasil pengujian sistem yang telah dilakukan, aplikasi penjualan telah memenuhi uji performance dan hasil pengujian dengan baik. Sehingga web aplikasi penjualan layak untuk digunakan dan diterapkan melalui localhost.

Dengan pengujian ini diharapkan pihak PT. SINKHOKKI dapat menyajikan informasi yang sesuai dengan kebutuhan pengguna yang tentunya sesuai yang diinformasik mengenai UU ITE 2018 pasal 9, yaitu : "Pelaku usaha yang menawarkan produk melalui Sistem Elektronik harus menyediakan informasi yang lengkap dan benar berkaitan dengan syarat kontrak, produsen, dan produk yang ditawarkan".

\section{KESIMPULAN}

Berdasarkan hasil penelitian yang telah dilakukan mengenai Implementasi Data Mart Penjualan pada PT. SINKHOKKI, maka dapat disimpulkan bahwa :

1. Dapat menghasilkan menu Dashboard di dalam aplikasi penjualan, dimana berfungsi untuk menampilkan laporan operasional Departement Inventory Control \& Departement Sales.

2. Dapat menghasilkan implementasi analisis Data Mart pada Departement Inventory Control \& Departement Sales, sehingga database dari kedua departemen tersebut dapat saling teringerasi.

3. Dapat menghasilkan implementasi metode OLTP pada aplikasi penjualan, dimana berfungsi sebagai alat transaksi yang user friendly.

4. Dengan melakukan pengujian sistem ini diharapkan memperoleh kebenaran informasi yang sah untuk kebutuhan pengguna sesuai dengan UU ITE tahun 20018, pasal 9.

Dengan adanya penelitian ini dapat membantu PT. SINKHOKKI untuk meningkatkan operasional perusahaan menjadi lebih baik lagi di dalam dunia bisnis yang kompetitif.

\section{DAFTAR PUSTAKA}

[1] Undang-Undang Republik Indonesia No. 11 Tahun 2008, tentang Informasi dan Transaksi Elektronik, http://bti.unpar.ac.id/undang-undang-ite/, (diakses : 04 April 2018)

[2] Abrahamsson, P., Salo, O., Ronkainen, J., \& Warsta, J. (2002). Agile Software Development Methods: Review and analysis, VTT publication 478, Espoo, Finland, 107p.

[3] Arifin., Kusrini., Luthfi, Emha T. (2014). Perancangan Dan Implementasi Data Warehouse Pemasaran Pada CV. 
Diandra Primamitra Media Yogyakarta. Yogyakarta: Seminar Nasional Teknologi Informasi dan Multimedia.
[4] Vercellis, C. (2009). Business Intelligence: Data mining And Optimization For Decision Making. Padstow: John Wiley \& Son Ltd. 